\title{
COMPARISON OF TWO METHODS FOR THE ESTIMATION OF STABILITY OF COPPER(II) BIS-COMPLEXES WITH AROMATIC LIGANDS RELEVANT TO ALZHEIMER'S DISEASE
}

\author{
Ante MILIČEVIĆ and Nenad RAOS \\ Institute for Medical Research and Occupational Health, Zagreb, Croatia \\ Received in July 2013 \\ CrossChecked in July 2013 \\ Accepted in August 2013
}

\begin{abstract}
In order to compare the density functional theory (DFT) and the method with the molecular valence connectivity index of the $3^{\text {rd }}$ order $\left({ }^{3} \chi^{v}\right)$ in the estimation of stability constants $\log \beta_{2}$, we used copper(II) complexes with thioflavin-based intercalation compounds designed for application in Alzheimer's disease. Correlation of ten $\log \beta_{2}$ values calculated by DFT with ${ }^{3} \chi^{v}$ yielded $r=0.988$ and S.E. $=0.85$. The correlations of indices $I_{\mathrm{NG}}, \mathrm{HOMA}$ and ${ }^{3} \chi^{\mathrm{v}}$ with $\log \beta_{2}$, and the intercorrelations between the indices revealed the crucial influence of ${ }^{3} \chi^{v}$ on the prediction of the stability of these complexes.
\end{abstract}

KEY WORDS: aromaticity, density-functional theory (DFT), regression models, stability constants, topological indices

Alzheimer's disease (AD), the leading mental disorder of the elderly population in developed countries, is closely related to copper metabolism (1). Next to the liver, the brain contains the second highest cellular concentration of copper, which is more frequent in grey matter $\left(60 \mu \mathrm{mol} \mathrm{L}^{-1}\right.$ to $\left.110 \mu \mathrm{mol} \mathrm{L}^{-1}\right)$ than in white matter $\left(25 \mu \mathrm{mol} \mathrm{L}^{-1}\right.$ to $\left.79 \mu \mathrm{mol} \mathrm{L}^{-1}\right)(2)$. Patients with AD have elevated copper(II) concentrations in whole blood (3). Even more importantly, copper(II) concentrations in the senile plaques of $\mathrm{AD}$ patients reach $400 \mu \mathrm{mol} \mathrm{L} \mathrm{L}^{-1}$, which is nearly four times as much as usual grey matter content (2). These findings led George J. Brewer, Emeritus Professor at the Michigan Medical School, to the hypothesis that AD could be caused by copper(II) poisoning $(4,5)$. This hypothesis is further supported by the finding that this disease is still virtually unknown in developing countries, as was the case in developed countries 50 to 60 years ago. Professor
Brewer found the principal reason for the epidemic of $\mathrm{AD}$ in elevated copper concentrations in drinking water caused by copper plumbing (6) and extensive red meat (especially beef) $(7,8)$ and multi-vitamin mineral pill consumption (9).

This hypothesis is also supported by research on the molecular level. The main mechanism in the development of $\mathrm{AD}$ is the formation of extracellular amyloid plaques in the brain. These plaques are composed of $\beta$-amyloid peptides (A $\beta)(10)$, a normal cleavage product of the larger membrane amyloid precursor protein (APP) (11). Human A $\beta$ binds copper, in contrast to rodent peptides (due to mutations Arg5 $\rightarrow$ Gly, Tyr10 $\rightarrow$ Phe, His $13 \rightarrow$ Arg). This serves as a very reasonable explanation for the virtual absence of $\mathrm{A} \beta$ deposits in normal rodent brains (12).

NMR (13) and AFM (14) studies have shown that copper(II) influences the aggregation behaviour of the A $\beta$ peptide. The second, more vital, influence of 
copper in the development of $\mathrm{AD}$ is the reduction of $\mathrm{Cu}^{2+}$ to $\mathrm{Cu}^{+}$via the $\mathrm{A} \beta$ peptide. This process directly produces hydrogen peroxide (15) and, subsequently, reactive oxygen species (ROS) $(16,17)$. Copper(II) chelators, especially ligands capable of binding to the $\mathrm{A} \beta$ peptide, are therefore viewed as potential drugs and diagnostic tools for the treatment of $\operatorname{AD}(18,19)$. Among these compounds is a class of ligands with a common core of the thioflavin T (ThT) and clioquinol (CQ) molecule (Figure 1). They were designed with the notion that they possess the lipophilicity adequate for crossing the blood-brain barrier as well as potential antioxidant properties. They also have a structure suitable for iodine substitution to the ligating group at the para position, which enables their use in diagnostics $(20,21)$.

After testing the ${ }^{3} \chi^{v}$ index on various copper(II) (23), bivalent transition metal (24), and lanthanide complexes (25), but not yet on aromatic compound complexes, we found these copper(II) chelators suitable for testing and developing our method for the prediction of stability constants of coordination compounds based on the connectivity index ${ }^{3} \chi^{v}(22)$. Unfortunately, among the ten complexes we studied, only two overall stability constants $\left(\beta_{2}\right)$ were measured (20). Thus, we correlated the ${ }^{3} \chi^{v}$ index to the stability constants $\left(\log \beta_{2}\right)$ calculated by the density functional theory (DFT) (21). Also, we studied the referred correlations (21) of aromatic indices $I_{\mathrm{NG}}$ and HOMA (used to investigate the influence of Möbius metalloaromaticity $(26,27)$ on stability) $v s . \log \beta_{2}$, to compare their influence with that of the ${ }^{3} \chi^{v}$ index.

\section{METHODS}

\section{Calculation of topological indices}

The molecular valence connectivity index of the $3^{\text {rd }}$ order ${ }^{3} \chi^{v}$ was calculated using the E-DRAGON program system, developed by R. Todeschini and coworkers, which is capable of yielding 119 topological indices in a single run, along with many other molecular descriptors $(28,29)$. The connectivity matrices were constructed with the aid of the Online SMILES Translator and Structure File Generator (30).

The ${ }^{3} \chi^{v}$ connectivity index (31-36) was defined as:

$$
{ }^{3} \chi^{v}=\sum_{\text {path }}[\delta(i) \delta(j) \delta(k) \delta(l)]^{-0.5}
$$

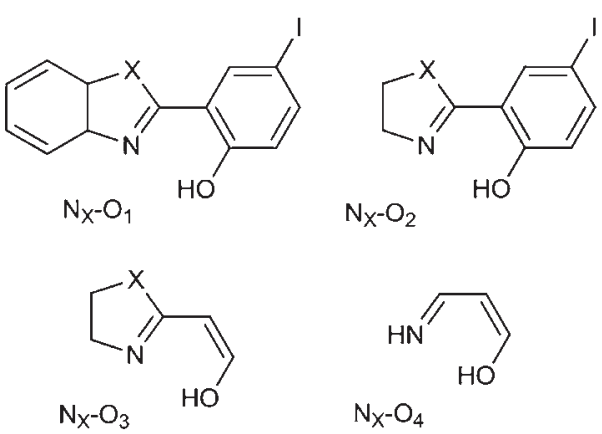

Figure 1 Constitutional formulas of aromatic ligands; $X$ is $\mathrm{NH}, \mathrm{O}$ or $\mathrm{S}$.

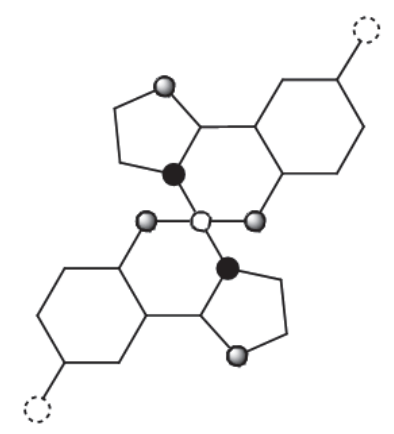

Figure 2 Graph representation of [Cu( $\left.\left.\mathrm{N}_{\mathrm{O}}-\mathrm{O} 2\right)_{2}\right]$. Heteroatoms are marked with $\bigcirc(\mathrm{Cu}), \bullet(N), \circ(\mathrm{O})$, and $(\mathrm{I})$.

where $\delta(i), \delta(j), \delta(k)$, and $\delta(l)$ are weights (valence values) of vertices (atoms) $i, j, k$, and $l$ making up the path of length 3 (three consecutive chemical bonds) in a vertex-weighted molecular graph. The valence value, $\mathrm{d}(i)$, of the vertex $i$ was defined by:

$$
\delta(i)=\left[Z^{v}(i)-H(i)\right] /\left[Z(i)-Z^{v}(i)-1\right]
$$

where $Z^{v}(i)$ is the number of valence electrons belonging to the atom corresponding to vertex $i, Z(i)$ its atomic number, and $H(i)$ the number of hydrogen atoms attached to it. It should be stressed that ${ }^{3} \chi^{v}$ is only a member of the family of valence connectivity indices ${ }^{n} \chi$, which differ among each other by path length, i.e. the number of $\delta$ 's in the summation term (Equation 1).

The ${ }^{3} \chi^{v}$ index for all bis-complexes was calculated from their graph representations assuming that the $\mathrm{Cu}(\mathrm{II})$ ion is tetracoordinated (Figure 2) (24).

\section{Regression calculations}

Regression calculations, including the leave-oneout procedure (LOO) of cross validation were done using the CROMRsel program (37). The standard error of the cross validation estimate was defined as: 


$$
\mathrm{S} . \mathrm{E}_{\mathrm{cv}}=\sqrt{\sum_{i} \frac{\Delta X_{i}^{2}}{N}}
$$

where $\Delta X$ and $N$ denote cv residuals and the number of reference points, respectively.

\section{RESULTS AND DISCUSSION}

In order to compare the efficiency of the two methods for the estimation of stability constants, DFT and the ${ }^{3} \chi^{v}$ index, we referred to $\log \beta_{2}$ DFT values (21) (Table 1). Although the DFT values $\{15.1$ and 11.0 for $\left[\mathrm{Cu}\left(\mathrm{N}_{\mathrm{O}}-\mathrm{O} 1\right)_{2}\right]$ and $\left[\mathrm{Cu}\left(\mathrm{N}_{\mathrm{S}}-\mathrm{O} 1\right)_{2}\right]$, respectively were far from their experimental values (23.1 and 20.3), as obtained by UV-VIS spectrometry (20), the authors had, by mistake, stated that the agreement was remarkable (21). However, if we direct our attention to the relative values of $\log \beta_{2} \mathrm{~s}$ obtained by either DFT or spectrophotometry, it is evident that $\log \beta_{2}\left[\mathrm{Cu}\left(\mathrm{N}_{\mathrm{O}}-\right.\right.$ $\left.\mathrm{O} 1)_{2}\right]>\log \beta_{2}\left[\mathrm{Cu}\left(\mathrm{N}_{\mathrm{S}}-\mathrm{O} 1\right)_{2}\right]$ for both methods, being 4.1 and 2.8 for DFT and spectrophotometry, respectively.

Bearing all this in mind, we reproduced $\log \beta_{2}$ (DFT) values through our method based on the ${ }^{3} \chi^{v}$ index. Simple regression (Figure 3) yielded a correlation coefficient of $r=0.988$ and a standard error of cross-validation of S.E. ${ }_{\mathrm{cv}}=0.97$ (Model 1, Table 2). Due to such a good correlation, we can deem our method equally successful as the DFT method, but much less demanding.

Table 1 Logarithm of stability constants of copper(II) bis-complexes with 10 aromatic ligands, and values of their metalloaromaticity $\left(\mathrm{I}_{N G}\right.$ and HOMA) and connectivity ${ }^{3} \chi^{v}$ indices.

\begin{tabular}{|c|c|c|c|c|c|c|}
\hline No. & complex & $\log \beta_{2}^{\text {[a] }}$ & $\log \beta_{2}^{[b]}$ & $I_{\mathrm{NG}}^{[\mathrm{cc}]}$ & HOMA $^{[c]}$ & ${ }^{3} \chi^{v}$ \\
\hline 1 & {$\left[\mathrm{Cu}\left(\mathrm{N}_{\mathrm{NH}}-\mathrm{O} 1\right)_{2}\right]$} & 15.1 & 15.7 & 0.0174 & 0.658 & 11.753 \\
\hline 2 & {$\left[\mathrm{Cu}\left(\mathrm{N}_{\mathrm{NH}}-\mathrm{O} 2\right)_{2}\right]$} & 19.1 & 19.0 & 0.0167 & 0.545 & 9.701 \\
\hline 3 & {$\left[\mathrm{Cu}\left(\mathrm{N}_{\mathrm{NH}}-\mathrm{O} 3\right)_{2}\right]$} & 24.1 & 24.6 & 0.0183 & 0.848 & 6.412 \\
\hline 4 & {$\left[\mathrm{Cu}\left(\mathrm{N}_{\mathrm{O}}-\mathrm{O} 1\right)_{2}\right]$} & 15.1 & 16.4 & 0.0174 & 0.659 & 11.404 \\
\hline 5 & {$\left[\mathrm{Cu}\left(\mathrm{N}_{\mathrm{O}}-\mathrm{O} 2\right)_{2}\right]$} & 18.8 & 19.6 & 0.0172 & 0.641 & 9.406 \\
\hline 6 & {$\left[\mathrm{Cu}\left(\mathrm{N}_{\mathrm{O}}-\mathrm{O} 3\right)_{2}\right]$} & 24.7 & 25.0 & 0.0188 & 0.915 & 6.130 \\
\hline 7 & {$\left[\mathrm{Cu}\left(\mathrm{N}_{\mathrm{S}}-\mathrm{O} 1\right)_{2}\right]$} & 11.0 & 11.0 & 0.0170 & 0.555 & 14.504 \\
\hline 8 & {$\left[\mathrm{Cu}\left(\mathrm{N}_{\mathrm{S}}-\mathrm{O} 2\right)_{2}\right]$} & 16.1 & 14.9 & 0.0172 & 0.572 & 12.036 \\
\hline 9 & {$\left[\mathrm{Cu}\left(\mathrm{N}_{\mathrm{s}}-\mathrm{O} 3\right)_{2}\right]$} & 22.8 & 20.6 & 0.0188 & 0.894 & 8.637 \\
\hline 10 & {$\left[\mathrm{Cu}(\mathrm{N}-\mathrm{O} 4)_{2}\right]$} & 30.8 & 30.9 & 0.0202 & 0.939 & 2.613 \\
\hline
\end{tabular}

[a] DFT values from Ref. 21

[b] Cross-validated values (Model 1, Table 2)

[c] Ref. 21

Table 2 Regression models for the estimation of the $\log \beta_{2}$ of $C u(I I)$ bis-complexes.

\begin{tabular}{|c|c|c|c|c|c|c|c|}
\hline \multirow{2}{*}{ model } & \multirow{2}{*}{ descriptor } & \multirow{2}{*}{ complexes } & \multicolumn{2}{|c|}{ regression coefficients } & \multirow{2}{*}{$r$} & \multirow{2}{*}{ S.E. } & \multirow{2}{*}{ S.E. ${ }_{\mathrm{cv}}$} \\
\hline & & & slope(S.E.) & intercept(S.E.) & & & \\
\hline 1 & \multirow{4}{*}{${ }^{3} \chi^{v}$} & all & $-1.667(91)$ & $35.20(89)$ & 0.988 & 0.85 & 0.97 \\
\hline 2 & & $1,2,3,10$ & $-1.693(46)$ & $35.17(39)$ & 0.999 & 0.23 & 0.40 \\
\hline 3 & & $4,5,6,10$ & $-1.785(17)$ & $35.54(14)$ & 0.999 & 0.08 & 0.21 \\
\hline 4 & & $7,8,9,10$ & $-1.65(13)$ & $35.8(14)$ & 0.994 & 0.84 & 2.44 \\
\hline 5 & \multirow{4}{*}{$I_{\mathrm{NG}}$} & all & $4711(897)$ & $-65(16)$ & 0.880 & 2.64 & 3.24 \\
\hline 6 & & $1,2,3,10$ & $4025(1372)$ & $-51(25)$ & 0.901 & 2.55 & 4.50 \\
\hline 7 & & $4,5,6,10$ & $4736(974)$ & $-65(18)$ & 0.960 & 1.67 & 3.06 \\
\hline 8 & & $7,8,9,10$ & $5608(768)$ & $-82(14)$ & 0.982 & 1.41 & 2.63 \\
\hline 9 & \multirow{4}{*}{ HOMA } & all & $31.9(66)$ & $-3.3(49)$ & 0.863 & 2.81 & 3.66 \\
\hline 10 & & $1,2,3,10$ & $32(14)$ & $-1(11)$ & 0.854 & 3.05 & 7.01 \\
\hline 11 & & $4,5,6,10$ & $39(12)$ & $-8.6(98)$ & 0.915 & 2.40 & 4.84 \\
\hline 12 & & $7,8,9,10$ & $39(11)$ & $-8.7(83)$ & 0.931 & 2.72 & 5.45 \\
\hline
\end{tabular}




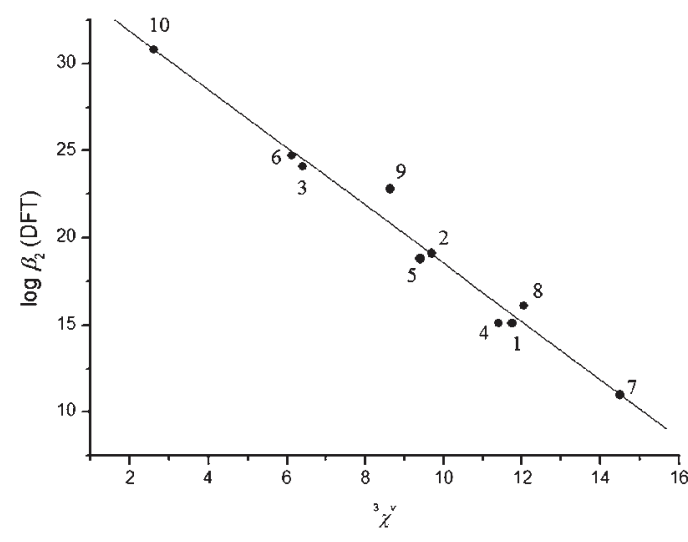

Figure 3 Dependence of stability constant $\log \beta,(D F T)$ on the ${ }^{3} \chi^{v}$ index for $\mathrm{Cu}(\mathrm{II})$ bis-complexes with ten aromatic ligands (Table 1, Model 1 in Table 2).

We also analysed reported correlations (24) of indices defining metalloaromaticity, $I_{\mathrm{NG}}$, and HOMA vs. $\log \beta_{2}$ (Models 6-8, 10-12, Table 2), on three subsets, imida-complexes (1-3 and 10), oxa-complexes (4-6 and 10), and thia-complexes (7-10). Although the stability was positively correlated with $I_{\mathrm{NG}}$ and HOMA for all three subsets, the differences in $\log \beta_{2}$ between complexes 1 and 2 and 4 and 5 showed an opposite trend. From the comparison of these correlations (Models 6-8, 10-12, Table 2) with the correlations obtained with the ${ }^{3} \chi^{v}$ index (Models 2-4, Table 2), it is clear that ${ }^{3} \chi^{v}$ is a substantially better index for modelling the stability of the studied complexes than $I_{\mathrm{NG}}$ and HOMA. Specifically, standard errors for ${ }^{3} \chi^{v}$ regressions are an order of magnitude smaller than the standard errors of the regressions with other two indices, with the exception of the thia-complexes subset [7-10, Table 1); S.E. $\left({ }^{3} \chi^{v}\right)$ :S.E. $\left(I_{\mathrm{NG}}\right)=1: 1.68$ and S.E. ${ }_{\mathrm{cv}}\left({ }^{3} \chi^{v}\right):$ S.E. ${ }_{\mathrm{cv}}\left(I_{\mathrm{NG}}\right)=1: 1.08$ (for HOMA the ratios are 1:3.24 and 1:2.23)]. Accordingly, the regression of ${ }^{3} \chi^{\prime}$ to $\log \beta_{2}$ on all complexes (Model 1, Table 2, Figure 3 ), yielded much better results than the regression with metalloaromaticity indices $I_{\mathrm{NG}}$ and HOMA(Models 5 and 9, Table 2, Figure 4).

Bivariate linear regressions of $I_{\mathrm{NG}}$ and ${ }^{3} \chi^{v} v s . \log$ $\beta_{2}\left(r=0.990\right.$, S.E. $=0.77$, S.E. $\left.{ }_{\mathrm{cv}}=1.11\right)$ and HOMA and ${ }^{3} \chi^{v}$ vs. $\log \beta_{2}\left(r=0.990\right.$, S.E. $=0.79$, S.E. $\left.{ }_{\mathrm{cv}}=1.19\right)$, did not yield improvement over univariate regression with ${ }^{3} \chi^{v}$. To the contrary, S.E. rose from 0.97 to 1.11 and 1.19 , respectively. In addition, the intercorrelations between ${ }^{3} \chi^{v}$ and indices $I_{\mathrm{NG}}$ and HOMA (Figure 5) show that the better the correlation of $I_{\mathrm{NG}}$ and HOMA to ${ }^{3} \chi^{v}$, the better the correlation of $I_{\mathrm{NG}}$ and HOMA to $\log \beta_{2}$ (Models 6-8, 10-12 in Table 2). All of the

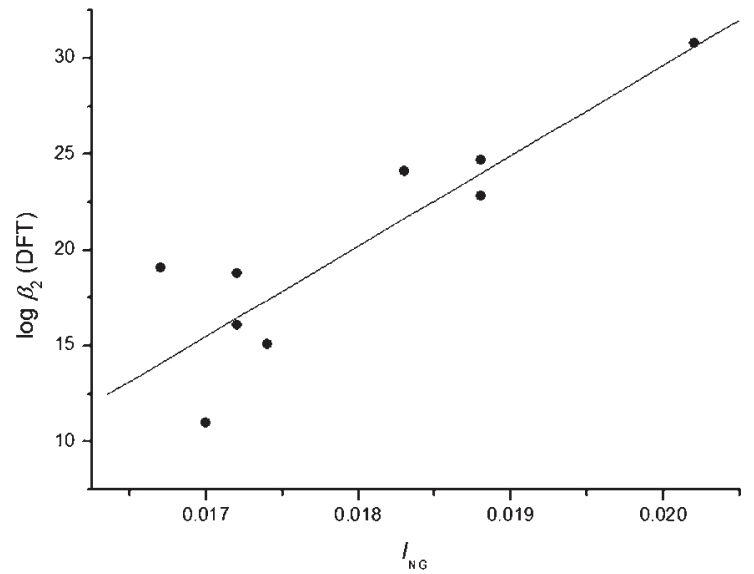

a)

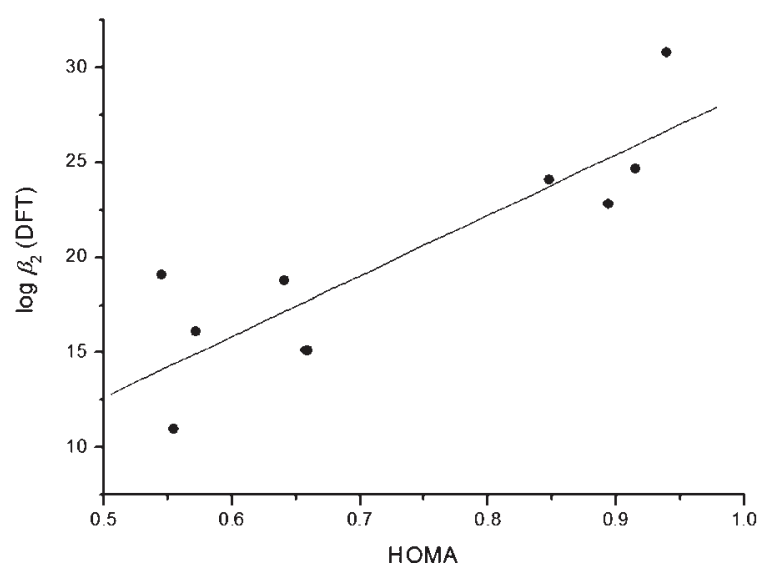

b)

Figure 4 Dependence of stability constant $\log \beta,(D F T)$, of $\mathrm{Cu}(\mathrm{II})$ bis-complexes with ten aromatic ligands, on a) $\mathrm{I}_{N G}$ index (Model 5, Table 2) and b) HOMA index (Model 9, Table 2).

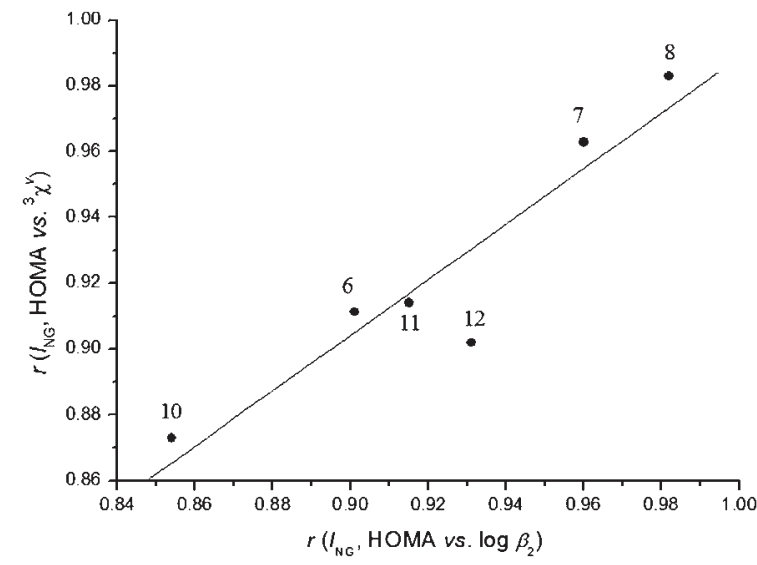

Figure 5 The correlation coefficient of $\mathrm{I}_{N G}$ and HOMA to ${ }^{3} \chi^{v}$ vs. the correlation coefficient of $I_{N G}$ and HOMA to $\log \beta_{2}$ (Models 6-8, 10-12 in Table 2). 
aforementioned strongly suggests that the information needed for stability modelling of the studied complexes stems almost exclusively from ${ }^{3} \chi^{v}$.

\section{CONCLUSION}

We correlated the ${ }^{3} \chi^{v}$ index to the stability constant $\log \beta_{2}$ calculated by the density functional theory (DFT). Assuming that DFT $\log \beta$ 's were fairly well correlated with experimental stability constants, we concluded that the method with ${ }^{3} \chi^{v}$ was equally good but far simpler for the estimation of stability constants in comparison to the DFT method. As DFT also proved unable to estimate the absolute $\log \beta_{2}$ values (21), it could not be ascertained, at least in our case, that DFT had any advantage over our method.

We also showed that ${ }^{3} \chi^{v}$ correlates to the $\log \beta_{2}$ of the studied complexes much better than metalloaromaticity indices $I_{\mathrm{NG}}$ and HOMA. Moreover, adding indices $I_{\mathrm{NG}}$ or HOMA into regression along with ${ }^{3} \chi^{v}$ worsened the estimates. This indicates that ${ }^{3} \chi^{v}$ encompasses structural information relevant to stability, including metalloaromaticity.

\section{Acknowledgements}

This work was supported by the Croatian Ministry of Science, Education and Sports (project 0221770495-2901).

\section{REFERENCES}

1. Kowalik-Jankowska T, Ruta-Dolejsz M, Wisniewska K, Lankiewicz L, Kozlowski H. Possible involvement of copper(II) in Alzheimer disease. Environ Health Perspect 2002;110(Suppl 5):869-70. PMID: 12426149

2. Lovell MA, Robertson JD, Teesdale WJ, Campbell JL, Markesbery WR. Copper, iron and zinc in Alzheimer's disease senile plaques. J Neurol Sci 1998;158:47-52. doi: 10.1016/s0022-510x(98)00092-6

3. Bocca B, Forte G, Petrucci F, Pino A, Marchione F, Bomboi G, Senofonte O, Giubilei F, Alimonti A. Monitoring of chemical elements and oxidative damage in patients affected by Alzheimer's disease. Ann Ist Super Sanità 2005;41:197203. PMID: 16244393

4. Brewer GJ. The risks of copper toxicity contributing to cognitive decline in the aging population and to Alzheimer's disease. J Am Coll Nutr 2009;28:238-42. PMID: 20150596

5. Brewer GJ, Newsome DA. Copper Proof: How Chronic Copper Toxicity is Causing the Epidemic of Alzheimer's Disease and Dementia. Ann Arbor: George J. Brewer Inc; 2009.
6. Sparks D, Friedland R, Retanceska S, Schreurs BG, Shi J, Perry G, Smith MA, Sharma A, Derosa S, Ziolkowski C, Stankovic G. Trace copper levels in the drinking water, but not zinc of aluminium, influence CNS Alzheimer's like pathology. J Nutr Health Aging 2006;10:247-54. PMID: 16886094

7. Waldman M, Lamb M. Dying for a Hamburger: Modern Meat Processing and the Epidemic of Alzheimer's Diesease. New York (NY): Thomas Dunne Books, St. Martin's Press; 2004.

8. Sinha R, Cross AJ, Graubard BI, Leitzmann MF, Schatzkin A. Meat intake and mortality: A perspective study of over half a million people. Arch Intern Med 2009;169:562-71. doi: 10.1001/archinternmed.2009.6

9. Morris MC, Evans DA, Tangney CC, Benias JL, Schneider JA, Wilson RS, Scherr PA. Dietary copper and high saturated and trans fat intakes associated with cognitive decline. Arch Neurol 2006;63:1085-8. doi: 10.1001/archneur.63.8.1085

10. Masters CL, Simms G, Weinman A, Multhaup G, McDonald BL, Beyreuther K. Amyloid plaque core protein in Alzheimer diesease and Down syndrome. Proc Natl Acad Sci USA 1985;82:4245-9. PMID: 3159021

11. Esch F, Keim PS, Beattie EC, Blacher RW, Culwell AR, Oltersdorf T, McClure D, Ward PJ. Cleavage of amyloid beta peptide during constitutive processing of its precursor. Science 1990;244:1122-4. doi: 10.1126/science.2111583

12. Otvos LJ, Szendrei GI, Lee VM, Mantsch HH. Human and rodent Alzheimer $\beta$-amyloid peptides acquire distinct conformations in membrane-mimicking solvents. Eur J Biochem 1993;211:249-57. doi: 10.1111/j.1432-1033.1993. tb19893.x

13. Hou L, Zagorski MG. NMR reveals anomalous copper(II) binding to amyloid $\mathrm{A} \beta$ peptide of Alzheimer's disease. J Am Chem Soc 2006;128:9260-1. doi: 10.1021/ja046032u

14. Innocenti M, Salvietti E, Guidotti M, Casini A, Bellandi S, Foresti ML, Gabbiani C, Pozzi A, Zatta P, Messori L. Trace copper(II) and zinc(II) ions drastically modify the aggregation behavior of amyloid- $\beta_{1-42}$ : An AFM study. J Alzheimer's Dis 2010;19:1323-9. doi: 10.3233/JAD-2010-1338

15. Huang X, Atwood CS, Hartshorn MA, Multhaup G, Goldstein LE, Scarpa RC, Cuajungco MP, Gray DN, Lim J, Moir RD, Tanzi RE, Bush AI. The A $\beta$ peptide of Alzheimer's disease directly produces hydrogen peroxide through metal ion reduction. Biochemirsty 1999;38:7609-16. doi: 10.1021/ bi990438f

16. Opazo C, Ruiz FH, Inestrosa NC. Amyloid- $\beta$-peptide reduces copper(II) to copper(I) independent of its aggregation state. Biol Res 2000;33:125-31. PMID: 15693279

17. Da Silva GFZ, Ming LJ. Alzheimer's disease related copper(II)- $\beta$-amyloid peptide exhibits phenol monooxygenase and catechol oxidase activities. Angew Chem Int Ed 2005;44:5501-4. doi: 10.1002/anie.200501013

18. Ferrada E, Arancibia V, Loeb B, Norambuena E, Olea-Azar C, Huidobro-Toro JP. Stoichiometry and conditional stability constants of $\mathrm{Cu}(\mathrm{II})$ or $\mathrm{Zn}(\mathrm{II})$ clioquinol complexes; implications for Alzheimer's and Huntington's disease therapy. Neurotoxicology 2007;28:445-9. doi: 10.1016/j. neuro.2007.02.004

19. Lim S, Paterson BM, Fodero-Tavoletti MT, O'Keefe GJ, Cappai R, Barnham KJ, Villemagne VL, Donnelly PS. A copper radiopharmaceutical for diagnostic imaging of Alzheimer's disease: a bis(thiosemicarbazonato)copper(II) 
complex that binds to amyloid-beta plaques. Chem Commun (Camb) 2010;46:5437-9. doi: 10.1039/c0cc01175d

20. Rodríguez-Rodríguez C, de Groot NS, Rimola A, ÁlvarezLarena Á, Lloveras V, Vidal-Gancedo J, Ventura S, Vendrell J, Sodupe M, González-Duarte P. Design, selection, and characterization of thioflavin-based intercalation compounds with metal chelating properties for application in Alzheimer's disease. J Am Chem Soc 2009;131:1436-51. doi: $10.1021 / \mathrm{ja} 806062 \mathrm{~g}$.

21. Rimola A, Alí-Torres J, Rodríguez-Rodríguez C, Poater J, Matito E, Solà M, Sodupe M. Ab initio design of chelating ligands relevant to Alzheimer's disease: Influence of metalloaromaticity. J Phys Chem A 2011;115:12659-66. doi: 10.1021/jp203465h

22. Raos N, Miličević A. Estimation of stability constants of coordination compounds using models based on topological indices. Arh Hig Rada Toksikol 2009;60:123-8. doi 10.2478/10004-1254-60-2009-1923

23. Miličević A, Raos N. Estimation of stability constants by graph-theoretical models. Binding of amino acids to copper(II) and nickel(II) complexes of iminodiacetates and pyridyl derivatives of aspartic acid. Int J Chem Model 2008;1:395-403.

24. Miličević A, Branica G, Raos N. Irving-Williams order in the framework of connectivity index ${ }^{3} \chi^{v}$ enables simultaneous prediction of stability constants of bivalent transition metal complexes. Molecules 2011;16:1103-12. doi: 10.3390/ molecules 16021103

25. Miličević A, Raos N. Modeling of stability constants of mono-complexes of $\mathrm{La}^{3+}, \mathrm{Ce}^{3+}, \mathrm{Pr}^{3+}$, and $\mathrm{Nd}^{3+}$ with carboxylic acids in water-dioxane solutions by using connectivity index ${ }^{3} \chi^{v}$. Chem Phys Lett 2012;528:63-7. doi: 10.1016/j. cplett.2012.01.023

26. Herges R. Topology in chemistry: designing Möbius molecules. Chem Rev 2006;106:4820-42. doi: 10.1021/ cr0505425
27. Mauksch M, Tsogoeva SB. Demonstration of "Möbius" aromaticity in planar metallacycles. Chem Eur J 2010;16:784351. doi: 10.1002/chem.201000396

28. Tetko IV, Gasteiger J, Todeschini R, Mauri A, Livingstone D, Ertl P, Palyulin VA, Radchenko EV, Zefirov NS, Makarenko AS, Tanchuk VY, Prokopenko VV. Virtual computational chemistry laboratory-design and description. J Comput Aid Mol Des 2005;19:453-63. doi: 10.1007/s10822-005-8694-y

29. VCCLAB, Virtual Computational Chemistry Laboratory [displayed 30 August 2013]. Available at http://www.vcclab. org

30. NCI/CADD Group. Online SMILES Translator and Structure File Generator [displayed 30 August 2013]. Available at http://cactus.nci.nih.gov/services/translate/

31. Randić M. On history of the Randić index and emerging hostility toward chemical graph theory. MATCH Commun Math Comput Chem 2008;59:5-124.

32. Kier LB, Hall LH. Molecular connectivity VII: specific treatment to heteroatoms. J Pharm Sci 1976;65:1806-9. PMID: 1032667

33. Kier LB, Hall LH. Molecular Connectivity in StructureActivity Analysis. New York (NY): John Wiley \& Sons; 1986.

34. Kier LB, Hall LH. Molecular Connectivity in Chemistry and Drug Research. New York (NY): Academic Press; 1976.

35. Randić M. On characterization of molecular branching. J Am Chem Soc 1975;97:6609-15. doi: 10.1021/ ja00856a001

36. Lučić B, Trinajstić N. Comparison between the sumconnectivity index and product-connectivity index for benzenoid hydrocarbons. Chem Phys Lett 2009;475:146-8. doi: 10.1016/j.cplett.2009.05.022

37. Lučić B, Trinajstić N. Multivariate regression outperforms several robust architectures of neural networks in QSAR modeling. J Chem Inf Comput Sci 1999;39:121-32. doi: 10.1021/ci980090f 


\section{Sažetak}

USPOREDBA DVIJU METODA ZA PROCJENU STABILNOSTI BIS-KOMPLEKSA BAKRA(II) S AROMATSKIM LIGANDIMA RELEVANTNIMA ZA ALZHEIMEROVU BOLEST

Izabrali smo komplekse bakra(II) s interkalacijskim spojevima temeljenima na tioflavinu, koji su namijenjeni za liječenje Alzheimerove bolesti, kako bismo usporedili teoriju funkcionala gustoće (DFT) s metodom molekularnog valencijskog indeksa 3. reda $\left({ }^{3} \chi^{v}\right)$ za procjenu vrijednosti konstanti stabilnosti $\log \beta_{2}$. Korelacija deset vrijednosti $\log \beta_{2}$ izračunatih metodom DFT s ${ }^{3} \chi^{\mathrm{v}}$ indeksom dala je $r=0,988$ i S.E. $=0,85$. Korelacije indeksa $I_{\mathrm{NG}}, \mathrm{HOMA} \mathrm{i}{ }^{3} \chi^{\mathrm{v}} \mathrm{s}$ vrijednostima $\log \beta_{2}$ te međukorelacije indeksa pokazuju bitan utjecaj ${ }^{3} \chi^{\mathrm{v}}$ na predviđanje stabilnosti istraživanih kompleksa.

KLJUČNE RIJEČI: aromatičnost, konstante stabilnosti, regresijski modeli, teorija DFT, topološki indeksi

\section{CORRESPONDING AUTHOR:}

Ante Miličević, $\mathrm{PhD}$

Institute for Medical Research and Occupational Health

Ksaverska cesta 2, 10000 Zagreb, Croatia

E-mail: antem@imi.hr 